\title{
Erratum to: Leadless Cardiac Pacemakers: Pacing Paradigm Change
}

Petr Neuzil $^{1}$

Published online: 14 September 2015

(C) Springer Science+Business Media New York 2015

Erratum to: Curr Cardiol Rep (2015) 17:68

DOI 10.1007/s11886-015-0619-3

There were originally two authors listed for this paper; however, Dr. Vivek Y. Reddy had no involvement with this article.

The online version of the original article can be found athttp://dx.doi.org/ 10.1007/s11886-015-0619-3.

$\triangle$ Petr Neuzil

pneuzil@seznam.cz

1 Cardiology Department, Na Homolce Hospital,

Prague, Czech Republic 